\title{
In vitro antiparasitic activity and chemical composition of the essential oil from Protium ovatum leaves (Burceraceae)
}

\author{
ELISÂNGELA B.B. ESTEVAM ${ }^{1}$, ISABELLA P.B. DE DEUS ${ }^{1}$, VANESSA P. DA SILVA ${ }^{1}$, \\ ELIZABETH A.J. DA SILVA ${ }^{1}$, CASSIA C.F. ALVES ${ }^{1}$, JOSÉ MILTON ALVES ${ }^{1}$, CRISTIANE \\ M. CAZAL ${ }^{2}$, LIZANDRA G. MAGALHÃES ${ }^{3}$, MARIANA C. PAGOTTI ${ }^{3}$, VIVIANE \\ R. ESPERANDIM ${ }^{3}$, ALEX F. SOUZA $^{4}$ and MAYKER L.D. MIRANDA ${ }^{5}$ \\ ${ }^{1}$ Instituto Federal de Ciência e Tecnologia Goiano, Campus Rio Verde, Av. Sul \\ Goiana, Zona Rural, 75901-970 Rio Verde, GO, Brazil \\ ${ }^{2}$ Instituto Federal do Sudeste de Minas, Campus Barbacena, Rua Monsenhor José \\ Augusto, 204, São José, 36205-018 Barbacena, MG, Brazil \\ ${ }^{3}$ Centro de Pesquisa em Ciências Exatas e Tecnologia, Universidade de Franca, Av. Dr. Armando \\ de Sáles Oliveira, 201, Parque Universitário, 14404-600 Franca, SP, Brazil \\ ${ }^{4}$ Instituto Federal de Educação, Ciência e Tecnologia de Mato Grosso do Sul, Campus \\ Coxim, Rua Salime Tanure, s/n, Santa Tereza, 79400-000 Coxim, MS, Brazil \\ ${ }^{5}$ Instituto Federal de Educação, Ciência e Tecnologia do Sul de Minas Gerais, Campus Pouso Alegre, \\ Av. Maria da Conceição Santos, 900, Parque Real, 37550-000 Pouso Alegre, MG, Brazil
}

Manuscript received on February 25, 2017; accepted for publication on June 14, 2017

\begin{abstract}
Leishmaniasis and trypanosomiasis are globally widespread parasitic diseases which have been responsible for high mortality rates. Since drugs available for their treatment are highly hepatotoxic, nephrotoxic and cardiotoxic, adherence to therapy has been affected. Thus, the search for new, more effective and safer drugs for the treatment of these diseases is necessary. Natural products have stood out as an alternative to searching for new bioactive molecules with therapeutic potential. In this study, the chemical composition and antiparasitic activity of the essential oil from Protium ovatum leaves against trypomastigote forms of Trypanosoma cruzi and the promastigote forms of Leishmania amazonensis were evaluated. The essential oil was promising against trypomastigote forms of $T$. cruzi $\left(\mathrm{IC}_{50}=28.55 \mu \mathrm{g} \cdot \mathrm{mL}^{-1}\right)$ and $L$. amazonensis promastigotes $\left(\mathrm{IC}_{50}=2.28 \mu \mathrm{g} \cdot \mathrm{mL}^{-1}\right)$. Eighteen chemical constituents were identified by Gas Chromatography coupled to Mass Spectrometry (GC-MS) in the essential oil, whose major constituents were spathulenol (17.6 \%), caryophyllene oxide (16.4\%), $\beta$-caryophyllene $(14.0 \%)$ and myrcene $(8.4 \%)$. In addition, the essential oil from $P$. ovatum leaves had moderate cytotoxicity against $\mathrm{LLCMK}_{2}$ adherent epithelial cell at the concentration range under analysis $\left(\mathrm{CC}_{50}=150.9 \mu \mathrm{g} \cdot \mathrm{mL}^{-1}\right)$. It should be highlighted that this is the first report of the chemical composition and anti-Trypanosoma cruzi and anti-Leishmania amazonensis activities of the essential oil from Protium ovatum leaves.
\end{abstract}

Key words: Trypanosoma cruzi, Leishmania amazonensis, essential oil, Protium ovatum, parasitic diseases.

Correspondence to: Mayker Lazaro Dantas Miranda

E-mail: mayker.miranda@ifsuldeminas.edu.br 


\section{INTRODUCTION}

Leishmaniasis, which is a disease caused by a digenetic protozoan of the genus Leishmania, has affected about two million people per year. It has also been considered an endemic disease in 88 countries, where about 350 million people are at risk (Neto et al. 2016). Its treatment is based on chemotherapeutic agents, which are pentavalent antimonial compounds $\left(\mathrm{Sb}^{+5}\right)$, and on amphotericin B. However, these chemotherapeutic agents are considered toxic (Antinarelli et al. 2015).

American trypanosomiasis, also known as Chagas disease, which is caused by Trypanosoma cruzi, can be transmitted to humans through feces of infected triatomine insects, contaminated food, blood transfusion and organs donated by infected donors (Delmondes et al. 2014). Nifurtimox and benzonidazole are prominent drugs in the treatment of Chagas disease, due to their efficacy in its acute phase and their tolerance (Delmondes et al. 2014).

The species Protium ovatum, which has been popularly known as almecega, is a shrub whose height ranges from 0.4 to $4 \mathrm{~m}$, blooms from April to September and yields fruits in September (Castelo et al. 2010). This species is native to Brazil and, although it occurs in both the Cerrado and the Amazon Forest biomes, it is more associated with savanna formations, such as the Cerrado (Lista de Espécies da Flora do Brasil 2016). The main characteristic of this genus is the production of resins, which are used in folk medicines, such as anti-inflammatory, immunostimulant, repellent, antinociceptive and antineoplastic ones (Dias et al. 2011).

Since natural products are important for the development and discovery of new drugs, the objective of this study was to describe the chemical composition and in vitro antiparasitic activity of the essential oil from Protium ovatum leaves, for the first time.

\section{MATERIALS AND METHODS}

\section{PLANT MATERIAL}

Leaves of $P$. ovatum were collected in the Cerrado region at the University of Rio Verde (UniRV), in Rio Verde, Goiás, Brazil (17 $47^{\prime} 53^{\prime} \mathrm{S}$ and $50^{\circ}$ $55^{\prime} 41$ " W) in July 2015. The plant was identified by the botanist Erika Amaral and a sample was deposited at the Herbarium Jataiense Professor Germano Guarim Neto at exsiccate number HJ 742.

\section{ESSENTIAL OIL EXTRACTION}

The essential oil was obtained from fresh leaves of P. ovatum (100 g), which were reduced by a knife mill and had their essential oil extracted by the hydrodistillation method carried out by a Clevenger type apparatus at $100{ }^{\circ} \mathrm{C}$ for $4 \mathrm{~h}$ (Xavier et al. 2016). Thereafter, the hydrolate was submitted to liquid-liquid partition in a separatory funnel. Three washes of the hydrolate were performed with three $10 \mathrm{~mL}$ portions of dichloromethane. Total oil yield was expressed as percentage $(\mathrm{g} / 100 \mathrm{~g}$ of fresh plant material). Essential oil samples were stored at -4 ${ }^{\circ} \mathrm{C}$ until further chemical and biological tests.

GC-MS ANALYSIS OF ESSENTIAL OIL

Gas Chromatography coupled to Mass Spectrometry (GC-MS) analysis was done by a Shimadzu QP2010 with an AOC-20i auto-injector using a DB-5MS column (30 m x $0.25 \mathrm{~mm}, 0.25 \mathrm{~mm}$ in thickness). The carrier gas was $\mathrm{He}$ at pressure of $57.4 \mathrm{kPa}$ and flow rate of $1.0 \mathrm{~mL} / \mathrm{min}$. The split ratio was $1 / 30$, the injector temperature was $250{ }^{\circ} \mathrm{C}$ and the injected volume was $0.1 \mu \mathrm{L}$. Temperature ranged between 60 and $240{ }^{\circ} \mathrm{C}$, having been increased $3{ }^{\circ} \mathrm{C} / \mathrm{min}$. MS were recorded on electron ionization (EI) mode, with ionization energy of $70 \mathrm{eV}$ (scan time: $2 \mathrm{scan} / \mathrm{s}$ ). The volatile chemical constituents were identified on the basis of their retention indices relative to a homologous series of $n$-alkanes $\left(\mathrm{C}_{10}-\mathrm{C}_{29}\right)$ and by comparing mass spectra 
with libraries (Wiley 7 and Nist 62) and references of previously published data (Adams 2007).

\section{LEISHMANICIDAL ACTIVITY AGAINST Leishmania amazonensis PROMASTIGOTE FORMS}

In order to evaluate leishmanicidal activity, $L$. amazonensis promastigote forms (MHOM/BR/ PH8) were maintained in RPMI 1640 (Gibco) culture medium supplemented with $10 \%$ fetal bovine serum. Subsequently, about $1 \times 10^{6}$ parasites were distributed on 96-well plates. The essential oil was previously dissolved in $100 \%$ dimethylsulfoxide (DMSO, stock solution $10 \mathrm{mg} \cdot \mathrm{mL}^{-1}$ (Synth)) and added to the cultures at concentrations from 1.56 to $50 \mu \mathrm{g} \cdot \mathrm{mL}^{-1}$. Amphotericin B was previously dissolved in $100 \%$ DMSO at concentration of $1 \mathrm{mg} \cdot \mathrm{mL}^{-1}$; afterwards, it was diluted in stock solution $500 \mu \mathrm{g} . \mathrm{mL}^{-1}$ in the culture medium (Synth) and added to cultures at concentrations from 0.19 to $3.12 \mu \mathrm{g} \cdot \mathrm{mL}^{-1}$. Cultures were incubated at $25{ }^{\circ} \mathrm{C}$ in BOD ovens (Quimis) for $24 \mathrm{~h}$ and the leishmanicidal activity was determined by growth inhibition of promastigote forms by counting the total number of live promastigotes in the Neubauer chamber (Global Glass, Porto Alegre, BR), considering flagellar motility. RPMI 1640 medium (Gibco) containing $0.5 \%$ DMSO (Synth) (highest concentration) was used as negative control and Amphotericin B (Eurofarma, São Paulo, BR) at $1 \mu \mathrm{g} \cdot \mathrm{mL}^{-1}$ concentration was used as positive control. Results were expressed as the mean of the lysis percentage relative to the negative control ( $0.1 \%$ DMSO). Two experiments were performed in triplicate. Determination of $50 \%$ inhibitory concentration values $\left(\mathrm{IC}_{50}\right)$ was carried out by non-linear regression curves of a GraphPad Prism version 5.0 Windows software (GraphPad software, USA). Maintenance of life cycle was approved by the Ethics Committee for Animal Care at the University of Franca, under protocol number 010/14.
In vitro EVALUATION OF TRYPANOCIDAL AND CYTOTOXIC ACTIVITIES

The in vitro trypanocidal trial was performed with the Trypanosoma cruzi Y strain, constituted by thin trypomastigote forms. This strain has been maintained at the Franca University Vivarium through successive tests in Swiss mice by cardiac puncture on the day of the parasitemic peak (seventh day of infection). This procedure was approved by the National Council for Control of Animal Experimentation of the Ethics Committee at the University of Franca, under protocol number 010/14.

The assay was performed with blood from infected albino mice by cardiac puncture at the parasitemic peak (seventh day of infection). The infected blood was diluted with physiological solution to achieve final blood concentration of $10^{6}$ trypomastigote forms. $\mathrm{mL}^{-1}$. Samples of the essential oils were diluted in DMSO and aliquots of this stock solution were added to the infected blood on the microtiter plate (96 wells), totalling $200 \mu \mathrm{L}$. In the trypanocidal trial, samples were evaluated in triplicate at concentrations of 400 , 200, 100, 50, 25, 12.5 and $6.25 \mu \mathrm{g} \cdot \mathrm{mL}^{-1}$. Regarding controls, the positive one was benzonidazole whereas the negative one was $0.5 \% \mathrm{DMSO}$ (atoxic concentration in this cell type). The microplate was incubated at $37{ }^{\circ} \mathrm{C}$ for 24 hours. Afterwards, the activity was quantitatively verified by counting the trypomastigote forms in agreement with the technique previously described in the literature (Rashed et al. 2016). Determination of the parasite lysis percentage was performed by comparison with the control group without treatment. Two experiments were performed in triplicate. Determination of $50 \%$ inhibitory concentration values $\left(\mathrm{IC}_{50}\right)$ was carried out by non-linear regression curves of a GraphPad Prism version 5.0 Windows software (GraphPad software, USA). 
LLCMK $_{2}$ adherent epithelial cells were grown in RPMI 1640 medium supplemented with $100 \mathrm{U} / \mathrm{mL}$ penicillin, $100 \mu \mathrm{g} \cdot \mathrm{mL}^{-1}$ streptomycin and $5 \%$ inactivated fetal calf serum. They were kept at $37{ }^{\circ} \mathrm{C}$ in $5 \% \mathrm{CO}_{2}$. A cell suspension was seeded at a concentration of $1 \times 10^{6}$ cells. $\mathrm{mL}^{-1}$ on a 96-well microplate with RPMI 1640 medium. Thereafter, adherent epithelial cells were treated with essential oil at different concentrations (6.25, $12.5,25,50,100,200$ and $\left.400 \mu \mathrm{g} \cdot \mathrm{mL}^{-1}\right)$. Plates were incubated at $37^{\circ} \mathrm{C}$ for $24 \mathrm{~h}$ and the biological activity was evaluated by the MTT colorimetric method [MTT; 3-(4,5-dimethylthiazol-2-yl)-2,5diphenyltetrazolium bromide] by a microplate reader at $540 \mathrm{~nm}$. RPMI 1640 medium was used as positive control whereas DMSO and RPMI 1640 media were used as negative ones. All experiments were performed in triplicate. The percentage of cell viability was determined by the following formula: $\%$ cell viability $=1-[(\mathrm{Y}-\mathrm{N}) /(\mathrm{N}-\mathrm{P})] \times 100$, where $\mathrm{Y}$ $=$ absorbance of wells containing cells and essential oil at different concentrations; $\mathrm{N}=$ negative control; and $\mathrm{P}=$ positive control (Esperandim et al. 2013).

\section{RESULTS AND DISCUSSION}

The essential oil from P. ovatum leaves yielded 0.3 $\%$, which is higher than the percentage previously found by Castelo et al. (2010) in a study developed with the same species. The essential oil from $P$. ovatum leaves was obtained and analyzed by GCMS to determine its composition. It was evaluated against $T$. cruzi and L. amazonensis to establish a possible antiparasitic effect. Twenty seven compounds were detected and 18 compounds were

TABLE I

Substances identified in the essential oil from Protium ovatum leaves.

\begin{tabular}{|c|c|c|c|c|}
\hline Substances & Retention time & $R I_{\text {Lit }}$ & $R I_{\text {exp }}$ & $\% R A$ \\
\hline$\alpha$-Pinene & 6.29 & 932 & 933 & 1.2 \\
\hline Sabinene & 7.51 & 969 & 972 & 1.8 \\
\hline$\beta$-Pinene & 7.63 & 974 & 976 & 2.1 \\
\hline Myrcene & 8.07 & 988 & 991 & 8.4 \\
\hline$\gamma$-3-Carene & 8.78 & 1008 & 1011 & 1.5 \\
\hline p-Cimene & 9.30 & 1020 & 1024 & 0.3 \\
\hline Limonene & 9.46 & 1024 & 1028 & 1.8 \\
\hline Terpinen-4-ol & 15.62 & 1174 & 1178 & 0.4 \\
\hline$\alpha$-Copaene & 24.17 & 1374 & 1376 & 6.4 \\
\hline Bourbonene & 24.52 & 1387 & 1386 & 0.3 \\
\hline$\beta$-Caryophyllene & 24.03 & 1417 & 1420 & 14.0 \\
\hline Spathulenol & 25.99 & 1577 & 1578 & 17.6 \\
\hline$\alpha$-Humulene & 27.39 & 1452 & 1453 & 1.3 \\
\hline Allo-Aromadendrene & 27.68 & 1458 & 1462 & 0.3 \\
\hline Dauca-5,8-diene & 28.50 & 1471 & 1471 & 0.6 \\
\hline Cubebol & 29.83 & 1515 & 1515 & 0.2 \\
\hline$\gamma$-Cadinene & 30.20 & 1522 & 1525 & 1.4 \\
\hline Caryophyllene oxide & 32.31 & 1582 & 1583 & 16.4 \\
\hline Monoterpenes & & & & 17.5 \\
\hline Sesquiterpenes & & & & 58.5 \\
\hline Total $(\%)$ & & & & 76.0 \\
\hline
\end{tabular}

$\boldsymbol{R I}_{\text {Lit }}$ : Retention index from the literature. $\boldsymbol{R I}_{\text {exp }}$ : Retention index relative to $n$-alkanes $\left(\mathrm{C}_{10}-\mathrm{C}_{29}\right)$ on the DB-5MS column. $\% \boldsymbol{R} \boldsymbol{A}$ : Relative area (peak area relative to the total peak in the GC-MS chromatogram), average of three replicates. 


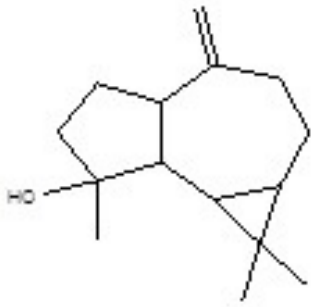

1

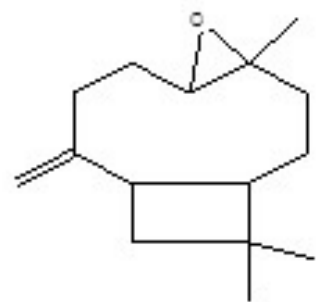

2

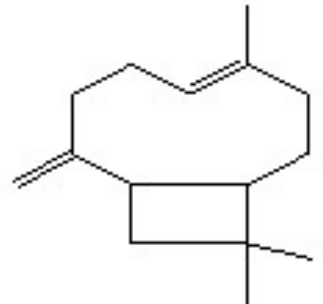

3

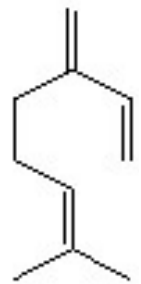

4

Figure 1 - Chemical structures of the four major constituents identified in the essential oil from P. ovatum leaves: (1) spathulenol, (2) caryophyllene oxide, (3) $\beta$-caryophyllene and (4) myrcene.

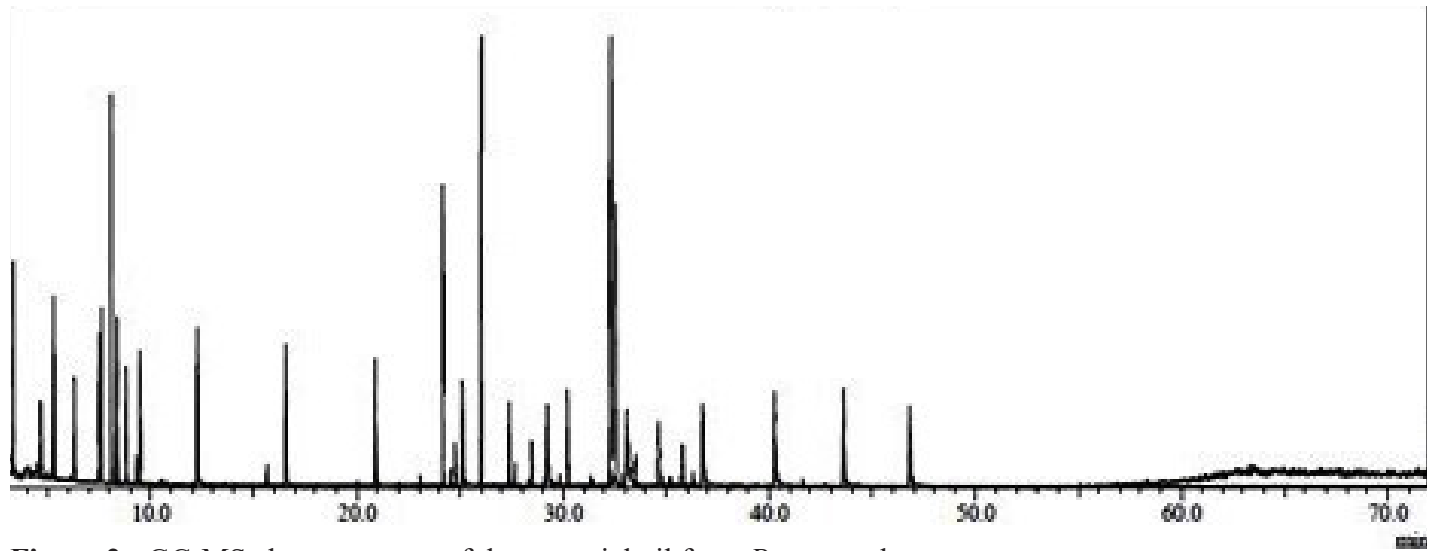

Figure 2 - GC-MS chromatogram of the essential oil from P. ovatum leaves.

identified (Table I, Figure 2). Major constituents were spathulenol $(17.6 \%, \mathbf{1})$, caryophyllene oxide $(16.4 \%, 2), \beta$-caryophyllene $(14.0 \%, 3)$ and myrcene $(8.4 \%, 4)$ (Figure 1). Spathulenol, caryophyllene oxide, $\beta$-caryophyllene and myrcene totalled $56.4 \%$ of the chemical composition of the essential oil from $P$. ovatum. Identified compounds, retention time, retention index and relative percentage (\%) are shown in Table I.

The chemical composition and biological properties of many essential oils have drawn the interest of researchers who have studied them widely in several areas (Estevam et al. 2016). In the literature, previous studies of essential oils from other species of the genus Protium showed similar chemical composition to the one found by this study. Sesquiterpene caryophyllene oxide $(16.4 \%)$ was identified as the major component in the essential oil from $P$. bahianum leaves and from leaves and branches of the $P$. hebetatum species (Moraes et al. 2013). Both compounds limonene (1.8\%) and $p$-cimene $(0.3 \%)$ were also found in the essential oil extracted from $P$. strumosum, $P$. altsonii and $P$. hebetatum resins (Zoghbi et al. 2005, Pinto et al. 2010). Compounds $\alpha$-pinene (1.2 \%) and myrcene $(8.4 \%)$ were identified at high concentrations in the essential oil from resins extracted from the $P$. heptaphyllum species (Siani et al. 2011). Relative concentration of spathulenol, by comparison with the concentration found in P. ovatum leaves (17.6 $\%$ ), was lower in essential oils from $P$. hebetatum leaves and branches (Pinto et al. 2010), P. pilosum leaves and $P$. strumosum resins (Zoghbi et al. 2005). In the analysis of the chemical composition of the essential oil from $P$. heptaphyllum leaves, sesquiterpene spathulenol was identified as one of the major constituents (Carvalho et al. 2013). 
Results of the evaluation of the leishmanicidal activity of the essential oil from $P$. ovatum leaves against the promastigote forms of $L$. amazonensis are shown in Table II.

$\mathrm{IC}_{50}$ value $=2.28 \mu \mathrm{g} \cdot \mathrm{mL}^{-1}$ is considered to be very promising by comparison with that of Amphotericin B $\left(\mathrm{IC}_{50}=0.60 \mu \mathrm{g} \cdot \mathrm{mL}^{-1}\right)$ (Table II). The literature describes that $\alpha$-pinene has recognised leishmanicidal activity against $L$. brasiliensis, a fact that may influence the antiparasitic activity of $P$. ovatum oil, even though this terpene is at concentration below $10 \%$ (Table I) (Sobral et al. 2014). In addition, the literature has shown that $\beta$-caryophyllene $(14.0 \%)$ is also active against parasites of the genus Leishmania (Meneguetti et al. 2015). It is a relevant fact since this terpene is found at a concentration above $10 \%$ in essential oil from $P$. ovatum leaves, a justification for the promising leishmanicidal potential of the species. Another important factor that can lead to good performance of antiparasitic activity is either the synergism of the major chemical constituents found in the essential oil or the presence of other constituents that can also be active at even lower concentrations (Melo et al. 2011).

It is relevant to mention the efficacy of the essential oils that have promising biological activities when the mixture of all their constituents, minor and major ones, is evaluated (Raut and Karuppayil 2014). It has been suggested, therefore, that minor constituents, due to the synergistic effect, are also crucial for the biological activities of essential oils (Silva et al. 2015a).

Essential oils of $P$. ovatum leaves also showed expressive trypanocidal activity when tested against trypomastigote forms of $T$. cruzi. An increase in the lysis of the parasites was observed as the concentration of the essential oil increased, with $\mathrm{IC}_{50}$ values of $28.55 \mu \mathrm{g} \cdot \mathrm{mL}^{-1}$ and benzonidazole $\left(\mathrm{IC}_{50}=9.8 \mu \mathrm{g} \cdot \mathrm{mL}^{-1}\right)$ as positive control (Table III).

TABLE II

Leishmanicidal activity of essential oil from $P$. ovatum leaves.

\begin{tabular}{|c|c|c|c|c|c|c|c|}
\hline \multirow[t]{2}{*}{ EO } & \multicolumn{6}{|c|}{$\%$ of lysis \pm S.D./Concentrations $\left(\mu \mathrm{g} . \mathrm{mL}^{-1}\right)$} & \multirow[t]{2}{*}{$\mathrm{IC}_{50}\left(\mu \mathrm{g} \cdot \mathrm{mL}^{-1}\right)$} \\
\hline & 50 & 25 & 12.5 & 6.25 & 3.12 & 1.56 & \\
\hline $\begin{array}{c}\text { Protium } \\
\text { ovatum }\end{array}$ & $90.54 \pm 2.25$ & $88.32 \pm 3.40$ & $79.55 \pm 1.36$ & $76.59 \pm 2.26$ & $58.17 \pm 4.06$ & $38.63 \pm 4.18$ & 2.28 \\
\hline \multirow{2}{*}{ Amph. B } & 3.12 & 1.56 & 0.78 & 0.39 & 0.19 & & \\
\hline & $98.14 \pm 0.44$ & $89.08 \pm 0.89$ & $75.73 \pm 1.17$ & $13.06 \pm 0.94$ & $4.87 \pm 1.31$ & - & 0.60 \\
\hline
\end{tabular}

EO: essential oil; Amph. B: Amphotericin B.

TABLE III

Trypanocidal activity of essential oil from $P$. ovatum leaves against $T$. cruzi trypomastigote forms.

\begin{tabular}{|c|c|c|c|c|c|c|c|c|}
\hline \multirow[t]{2}{*}{ EO } & \multicolumn{7}{|c|}{$\%$ of lysis \pm S.D./Concentration $\left(\mu \mathrm{g} . \mathrm{mL}^{-1}\right)$} & \multirow[t]{2}{*}{$\mathrm{IC}_{50}\left(\mu \mathrm{g} \cdot \mathrm{mL}^{-1}\right)$} \\
\hline & 6.25 & 12.5 & 25 & 50 & 100 & 200 & 400 & \\
\hline $\begin{array}{c}\text { Protium } \\
\text { ovatum }\end{array}$ & $23.76 \pm 2.94$ & $32.58 \pm 1.12$ & $41.40 \pm 1.37$ & $58.44 \pm 3.73$ & $76.38 \pm 10.55$ & $99.25 \pm 0.93$ & $100 \pm 0$ & 28.55 \\
\hline
\end{tabular}

EO: essential oil; S.D.: standard deviation; positive control: benzonidazole $\left(\mathrm{IC}_{50}=9.8 \mu \mathrm{g} \cdot \mathrm{mL}^{-1}\right)$.

TABLE IV

Cytotoxic activity of essential oil from Protium ovatum leaves.

\begin{tabular}{|c|c|c|c|c|c|c|c|c|}
\hline & & & of lysis \pm & D./Concentr & on $\left(\mu \mathrm{g} \cdot \mathrm{mL}^{-1}\right.$ & & & $\mathbf{C C}_{50}\left(\mu \mathrm{g} \cdot \mathrm{mL}^{-1}\right)$ \\
\hline & 6.25 & 12.5 & 25 & 50 & 100 & 200 & 400 & \\
\hline EO & $100 \pm 0$ & $85.2 \pm 1.8$ & $80.3 \pm 1.5$ & $72.9 \pm 1.7$ & $42.8 \pm 1.1$ & $35.6 \pm 1.4$ & $30.7 \pm 1.7$ & 150.9 \\
\hline
\end{tabular}

EO: essential oil from Protium ovatum leaves. S.D.: standard deviation. 
The trypanocidal activity of the essential oil from $P$. ovatum leaves is described by this paper for the first time. The literature describes that samples with $\mathrm{IC}_{50}<10 \mu \mathrm{g} \cdot \mathrm{mL}^{-1}$ had highly active trypanocidal activity, whereas others were active $\left(\mathrm{IC}_{50}>10<50 \mu \mathrm{g} \cdot \mathrm{mL}^{-1}\right)$, moderately active $\left(\mathrm{IC}_{50}>\right.$ $\left.50<100 \mu \mathrm{g} \cdot \mathrm{mL}^{-1}\right)$ and inactive $\left(\mathrm{IC}_{50}>100 \mu \mathrm{g} \cdot \mathrm{mL}^{-1}\right)$ (Estevam et al. 2016).

The promising trypanocidal activity exhibited by the essential oil from $P$. ovatum leaves can be justified by the following terpenes: $\beta$-caryophyllene $(14.0 \%)$, $p$-cymene $(0.3 \%)$, limonene $(1.8 \%)$, spathulenol (17.6\%) and caryophyllene oxide (16.4 $\%$ ), as previously identified in the essential oil from different species of Lippia spp, with recognised antiparasitic activity (Escobar et al. 2010). The compound $\alpha$-pinene $(1.2 \%)$, which is also found in the essential oil from Schinus terebinthifolius, has recognised trypanocidal activity (Sartorelli et al. 2012). Other notable compounds identified in the essential oil from $P$. ovatum leaves have already had their antiparasitic activity reported by the literature are: myrcene $(8.4 \%)$, sabinene $(1.8 \%)$, terpinen-4-ol (0.4\%) and $\beta$-pinene (2.1\%) (Silva et al. 2015b). To sum up, bioactive compounds that were identified by this study in the essential oil from $P$. ovatum leaves may justify the promising anti-Trypanosoma cruzi and anti-Leishmania amazonensis activities that it found.

Regarding cytotoxic activity, cultures of $\mathrm{LLCMK}_{2}$ adherent epithelial cells were treated with essential oil at concentrations of 6.25, 12.5, 25.0, 50.0, 100, 200 and $400 \mu \mathrm{g} \cdot \mathrm{mL}^{-1}$ for $24 \mathrm{~h}$. Results showed that the essential oil from leaves have moderate toxicity at the concentration evaluated with $\mathrm{CC}_{50} 150.9 \mu \mathrm{g} \cdot \mathrm{mL}^{-1}$ (Table IV), by comparison with benzonidazole positive control, with $\mathrm{CC}_{50}$ $147.3 \mu \mathrm{g} . \mathrm{mL}^{-1}$.

Essential oil from $P$. ovatum fresh leaves was classified as moderately cytotoxic $\left(\mathrm{CC}_{50}>100<\right.$ $\left.1000 \mu \mathrm{g} \cdot \mathrm{mL}^{-1}\right)$, by comparison with data found in the literature (Alves et al. 2012). The moderate cytotoxicity of this oil is an indicator of the fact that this plant can be well tolerated by the biological system. However, further detailed studies are required to evaluate the toxicity of these bioactive oils with other models in vivo. There is evidence that essential oils have low density and rapid diffusion across cell membranes because of their lipid solubility. As a result, they could damage the parasite cell membrane structure, which would lead to cellular lysis (Anthony et al. 2005). In addition, there could be synergistic and/or additive effects of the constituents of essential oils (Melo et al. 2011).

\section{CONCLUSIONS}

To sum up, results of this study showed that the essential oil from Protium ovatum leaves found in the Brazilian Cerrado, which is located in the country's central-west region, has promising antiparasitic potential with moderate cytotoxicity towards $\mathrm{LLCMK}_{2}$ adherent epithelial cells. The chemical composition of the essential oil from $P$. ovatum leaves had a mixture of mono and sesquiterpenes and its major constituents were spathulenol, caryophyllene oxide, $\beta$-caryophyllene and myrcene. Since diseases caused by the parasites under investigation affect millions of people worldwide, results of this study are relevant because the chemical composition of the essential oil from $P$. ovatum leaves was described for the first time. It is noteworthy that, in the face of medical advances, plants are still considered promising sources and bioactive compounds found in essential oils from plants of the genus Protium may serve as prototypes for the development of new antiparasitic drugs.

\section{REFERENCES}

ADAMS RP. 2007. In Identification of Essential Oil Components by Gas Chromatography/Quadrupole Mass Spectroscopy, $4^{\text {th }}$ ed., Allured Publishing Corporation: Carol Stream, IL, 804 p. 
ALVES RT, REGASINI LO, FUNARI CS, YOUNG MCM, RIMOLDI A, BOLZANI VS, SILVA DHS, ALBUQUERQUE S AND ROSA JA. 2012. Trypanocidal activity of Brazilian plants against epimastigote forms from Y and Bolivia strains of Trypanosoma cruzi. Braz J Pharmacog 22: 528-533.

ANTHONY JP, FYFE L AND SMITH H. 2005. Plant active components - a resource for antiparasitic agents? Trends Parasitol 21: 462-468.

ANTINARELLI LMR, PINTO NC, SCIO E AND COIMBRA ES. 2015. Antileishmanial activity of some Brazilian plants, with particular reference to Casearia sylvestris. An Acad Bras Cienc 87: 733-742.

CARVAlHO LE, MAGALHÃES LAM, LIMA MP, MARQUES MOM AND FACANALI R. 2013. Essential oils of Protium of the Adolpho Ducke Forest Reserve: Protium crassipetalum, $P$. heptaphyllum subs. Ulei, $P$. pilosissimum and P. polybotryum. J Essent Oil Bearing Plants 16: 551-554.

CASTELO AVM, MENEZZI CHSD AND RESCK IS. 2010. Rendimento e análises espectroscópicas $\left(\mathrm{RMN}{ }^{1} \mathrm{H},{ }^{13} \mathrm{C}\right.$, IV) da composição química dos óleos essenciais de quatro plantas do Cerrado. Cerne Lavras 16: 573-584.

DELMONDES GA ET AL. 2014. Avaliação da citotoxidade e atividade leishmanicida e tripanocida de extratos de Passiflora cincinnata Mast L. Cad Cult Cienc 13: 31-38.

DIAS MO, HAMERSKI L AND PINTO AC. 2011. Separação semipreparativa de $\alpha$ e $\beta$ - amirina por cromatografia líquida de alta eficiência. Quim Nova 34: 704-706.

ESCOBAR P, LEAL SM, HERRERA LV, MARTINEZ JR AND STASHENKO E. 2010. Chemical composition and antiprotozoal activities of Colombian Lippia spp essential oils and their major components. Mem Inst Oswaldo Cruz 105: 184-190.

ESPERANDIM VR ET AL. 2013. In vitro antiparasitic activity and chemical composition of the essential oil obtained from the fruits of Piper cubeba. Planta Med 79: 1653-1655.

ESTEVAM EBB ET AL. 2016. Composição química e atividades biológicas dos óleos essenciais das folhas frescas de Citrus limonia Osbeck e Citrus latifolia Tanaka (Rutaceae). Rev Virtual Quim 8: 1842-1854.

LISTA DE ESPÉCIES DA FLORA DO BRASIL. 2016. Jardim Botânico do Rio de Janeiro. <http://floradobrasil.jbrj.gov. br/jabot/FichaPublicaTaxonUC/FichaPublicaTaxonUC. do?id=FB16660 $>$ [Consultado em 12 de Setembro de 2016].

MELO NI ET AL. 2011. Schistosomicidal activity of the essential oil of Ageratum conyzoides L. (Asteraceae) against adult Schistosoma mansoni worms. Molecules 16: 762-773.

MENEGUETTI DUO, LIMA RA, MACEDO SRA, BARROS NB, FACUNDO JB, MILITÃO JSLT, NICOLETE R AND
FACUNDO VA. 2015. Plantas da Amazônia com potencial leishmanicida in vitro. Rev Patol Trop 44: 359-374.

MORAES MMM, CAMARA CAG AND RAMOS CS. 2013. Seasonal variation in the essential oil Protium bahianum daly (Burseraceae). J Essent Oil Bearing Plants 16: 300-307.

NETO BM, LEITÃO JMRS, OLIVIERA LGC, SANTOS EMS, CARNEIRO SMP, RODRIGUES KAF, CHAVES MH, ARCANJO DDR AND CARVALHO FAA. 2016. Inhibitory effects of Zanthoxylum rhoifolium Lam. (Rutaceae) against the infection and infectivity of macrophages by Leishmania amazonensis. An Acad Bras Cienc 88: 1851-1861.

PINTO DS, CARVALHO LE, LIMA MP, MARQUES OM, FACANALI R AND RIBEIRO JELS. 2010. Volatiles of foliar rachis, branches and resin elicited by insects from Protium hebetatum grown wild in the Amazon. J Essent Oil Bearing Plants 13: 699-703.

RASHED K, FERREIRA DS, ESPERANDIM VR, MARÇAL MG, SEQUEIRA BM, FLAUZINO LGB AND CUNHA WR. 2016. In vitro trypanocidal activity of the Egyptian plant Schinopsis lorentizii against trypomastigote and amastigote forms of Trypanosoma cruzi. J Appl Pharm Sci 6: 055-060.

RAUT JS AND KARUPPAYIL SM. 2014. A status review on the medicinal properties of essential oils. Ind Crops Prod 62: 250-264.

SARTORELLI P, SANTANA JS, GUADAGNIN RC, LAGO JHG, PINTO EG, TEMPONE AG, STEFANI HÁ, SOARES MG AND SILVAAM. 2012. In vitro trypanocidal evaluation of pinane derivatives from essential oil of ripe fruits from Schinus terebinthifolius Raddi (Anacardiaceae). Quim Nova 35: 743-747.

SIANI AC, RAMOS MFS, MONTEIRO SS, SANTOS RR AND SOARES ROA. 2011. Essential oils of the oleoresins from Protium heptaphyllum growing in Southeast Brazil and their cytotoxicity to neoplasic cells lines. J Essent Oil Bearing Plants 14: 373-378.

SILVA CEL, MINGUZZI S, SILVA RCL, MATOS MFC, TOFOLI D, CARVALHO JE, RAUIZ ALTG, COSTA WF AND SIMIONATTO E. 2015a. Chemical composition and cytotoxic activity of the root essential oil from Jatropha ribifolia (Pohl) Baill (Euphorbiaceae). J Braz Chem Soc 26: 233-238.

SILVA LE, REIS RA, MOURA EA, AMARAL W AND SOUSA JR PT. 2015b. Plantas do gênero Xylopia: composição química e potencial farmacológico. Rev Bras Pl Med 17: 814-826.

SOBRAL-SOUZA CE ET AL. 2014. Avaliação da atividade citotóxica e potencial antiparasitário in vitro do $\alpha$ - pineno e carvacrol. Acta toxicol Argent 22: 76-80.

XAVIER MN, ALVES JM, CARNEIRO NS, SOUCHIE EL, SILVA EAJ, MARTINS CHG, AMBROSIO MALV, EGEA MB, ALVES CCF AND MIRANDA MLD. 2016. 
Composição química do óleo essencial de Cardiopetalum calophyllum Schltdl. (Annonaceae) e suas atividades antioxidante, antibacteriana e antifúngica. Rev Virtual Quim 8: 1433-1448.
ZOGHBI MGB, ANDRADE EHA, LIMA MP, SILVA TMD AND DALY DC. 2005. The essential oils of five species of Protium growing in the North of Brazil. J Essent Oil Bearing Plants 8: 312-317. 